\title{
Drug hypersensitivity in children in Brazil
}

\author{
Luis Felipe Ensina ${ }^{1 *}$, Ines Cristina Camelo-Nunes ${ }^{1}$, Mara Morelo Felix², Maria Fernanda Malaman ${ }^{3}$, Gladys Queiroz ${ }^{4}$, \\ Djanira Martins Andrade ${ }^{1}$, Ligia de Oliveira Machado ${ }^{1}$, Alex Eustaquio Lacerda', Camila Teles Machado Pereira', \\ Dirceu Sole ${ }^{1}$
}

From 6th Drug Hypersensitivity Meeting (DHM 6)

Bern, Switzerland. 9-12 April 2014

\section{Background}

Drug hypersensitivity is one of the most frequent reasons for consultations with an allergist in Brazil. However, drug hypersensitivity epidemiology data in children is scarce. The aim of this study was to investigate children reporting suspected drug hypersensitivity reaction (DHR).

\section{Methods}

From June 2011 to December 2013 a prospective observational study was implemented in 4 allergology units from different regions of Brazil. Children reporting DHR were evaluated using a modified ENDA questionnaire, and a standardized diagnostic work up was performed.

\section{Results}

Ninety patients were evaluated, 54 male, with a median age of 6 years. Personal history of atopy was reported in 65 and previous DHR in 9. Cutaneous manifestations were observed in 86 - urticaria and/or angioedema in 71 and macular or maculopapular exanthema in 15 . Other symptoms reported were: respiratory (25), gastrointestinal (8), cardiovascular (5). The interval between dose and reaction was less than 1 hour in 38 subjects. Mild reaction was observed in 32 patients and moderate in 55 . Fever and/or viral infection were present in 61 patients during or just before the reaction. The majority of subjects were treated in emergency units (79). More than one drug was suspected as a trigger in 50 children (NSAIDs in $50 \%$, beta-lactam antibiotics in $31 \%$ and other antibiotics in 8.5\%). Sixteen skin tests (prick and intradermal) were performed and were all negative but one with amoxicilin. Drug provocation tests were positive in 4 of 51 tests NSAIDs 29 (4 positive), beta-lactam antibiotics 20 and others 4. Sixty-one reactions were possible or probable

${ }^{1}$ Federal University of Sao Paulo, Allergy, Immunology and Rheumatology, Brazil

Full list of author information is available at the end of the article related with the suspected drug, but in 25 this relation was unlikely.

\section{Conclusions}

Children with a suspected history must be fully investigated to confirm or exclude the diagnosis of DHR.

\begin{abstract}
Authors' details
${ }^{1}$ Federal University of Sao Paulo, Allergy, Immunology and Rheumatology, Brazil. ${ }^{2}$ Hospital Federal dos Servidores do Estado do Rio de Janeiro, Allergy and Immunology, Brazil. ${ }^{3}$ Universidade Tiradentes, Allergy and Immunology, Brazil. ${ }^{4}$ Federal University of Pernambuco, Pediatrics, Brazil.
\end{abstract}

Published: 18 July 2014

doi:10.1186/2045-7022-4-S3-P145

Cite this article as: Ensina et al:: Drug hypersensitivity in children in Brazil. Clinical and Translational Allergy 2014 4(Suppl 3):P145.

\section{Submit your next manuscript to BioMed Central and take full advantage of: \\ - Convenient online submission \\ - Thorough peer review \\ - No space constraints or color figure charges \\ - Immediate publication on acceptance \\ - Inclusion in PubMed, CAS, Scopus and Google Scholar \\ - Research which is freely available for redistribution \\ Submit your manuscript at www.biomedcentral.com/submit}

() Biomed Central

(C) 2014 Ensina et al; licensee BioMed Central Ltd. This is an Open Access article distributed under the terms of the Creative Commons Attribution License (http://creativecommons.org/licenses/by/4.0), which permits unrestricted use, distribution, and reproduction in any medium, provided the original work is properly cited. The Creative Commons Public Domain Dedication waiver (http:// creativecommons.org/publicdomain/zero/1.0/) applies to the data made available in this article, unless otherwise stated. 